\title{
Empathetic Language of Leadership in Religious-based Non- Profit Organizations: The Case of Waqf Institutions in Malaysia
}

Sharfizie Mohd Sharip, Marinah Awang, Ramlee Ismail

To Link this Article: http://dx.doi.org/10.6007/IJARBSS/v10-i10/7937

DOI:10.6007/IJARBSS/v10-i10/7937

Received: 25 July 2020, Revised: 12 August 2020, Accepted: 16 September 2020

Published Online: 23 October 2020

In-Text Citation: (Sharip, Awang, \& Ismail, 2020)

To Cite this Article: Sharip, S. M., Awang, M., \& Ismail, R. (2020). Empathetic Language of Leadership in Religious-based Non-Profit Organizations: The Case of Waqf Institutions in Malaysia. International Journal of Academic Research in Business and Social Sciences. 10(10), 217-587.

\section{Copyright: (c) 2020 The Author(s)}

Published by Human Resource Management Academic Research Society (www.hrmars.com)

This article is published under the Creative Commons Attribution (CC BY 4.0) license. Anyone may reproduce, distribute, translate and create derivative works of this article (for both commercial and non-commercial purposes), subject to full attribution to the original publication and authors. The full terms of this license may be seen at: http://creativecommons.org/licences/by/4.0/legalcode

Vol. 10, No. 10, 2020, Pg. 217 - 587 


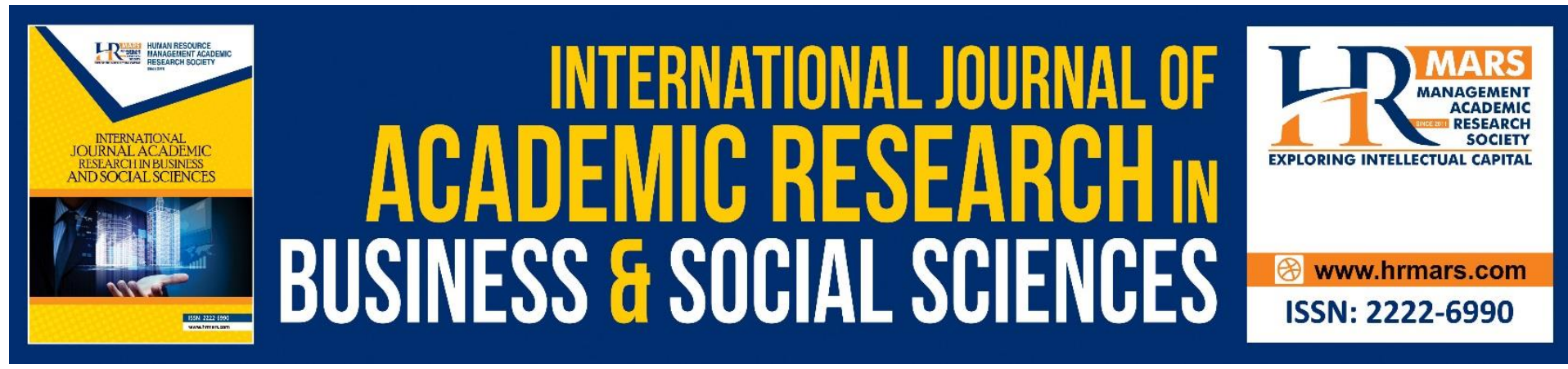

\title{
Empathetic Language of Leadership in Religious- based Non-Profit Organizations: The Case of Waqf Institutions in Malaysia
}

\author{
Sharfizie Mohd Sharipa ${ }^{\mathrm{a}}$, Marinah Awang ${ }^{\mathrm{b}}$, Ramlee Ismail \\ a Faculty of Business and Management, Universiti Teknologi MARA (UiTM), Rembau, 71300, \\ Malaysia, b,c Faculty of Management and Economics, Tanjung Malim,35900, Malaysia \\ Email:sharfizie@uitm.edu,my
}

\begin{abstract}
This study aims to extend the empathetic language model derived from the motivating language theory. Empathetic language provides a model of how leaders can understand their subordinates via the emphasis on emotional support, specifically the selection of words, which is proposed to affect management effectiveness. This paper also proposes the moderating effect of LMX in the relationship between empathetic language and management effectiveness. The current finding indicates a non-significant relationship between empathetic language and management effectiveness due to the prevalence of a power distance culture in the context of Malaysia. However, the relationship was found to be significant when moderated by Leader-Member Exchange. These findings enrich the existing body of knowledge about empathetic language and management effectiveness among NPOs.
\end{abstract}

\section{Introduction}

There has been increasing pressure on NPOs to evaluate their operations and demonstrate their competence and credibility. Waqf institutions are also affected particularly due to the numerous and long unresolved problems that raised questions about their integrity and accountability (Sharfizie et al., 2019a). Thus, more effective and ethical leadership skills are required to enhance the survival and continuity of these institutions. Empathetic language is a pivotal $21^{\text {st }}$ century leadership tool on top of good interpersonal relationship skills among leaders which has been proven to improve both employee and organisational performance. This study examines the effect of empathetic language usage by leaders on the management effectiveness of Waqf institutions, and investigates the moderating role of Leader-Member Exchange (LMX).

Waqf institutions are religious-based non-profit organisations (NPOs) (Kahf, 2003; Thaker et al., 2016) categorised under the third sector organisation (TSO) (Mohd Arshad \& Mohamed Haneef, 2016) of which objective is to uphold justice and human wellbeing. NPOs are basically identified as part of the non-profit sector, the third sector or voluntary sector (Kolb, 2018). NPOs are fundamentally focused on creating social values as opposed to generating profits (Othman et al., 2012). They aim to serve the community or undertake other non-profit initiatives (Pervez, 2006). The management of NPOs are often viewed as incompetent or 
poorly trained as compared to commercially-driven organizations (Morris et al., 2011). Hasan \& Siraj, (2017) asserted that Waqf institutions have lost a significant effect on the economy due to dwindling public trust which resulted in less donor involvement. All this indicates that these institutions need to raise their level of competitiveness which would in turn ensure their viability and the achievement of their social objectives. Towards that end, effective leadership leading to effective management is pertinent. Moreover Sharfizie et al., (2019b) argue that effective leaders are crucial in building camaraderie that leads to producing coordination which in turn enhancing the overall effectiveness of management.

Effective leadership is a critical $21^{\text {st }}$ century element in organizational management (Holt \& Marques, 2012). Leaders need to have the immeasurable capabilities of identifying changes, motivating people and providing support, with a critical emphasis on situational leadership for facing various circumstances (Dumas \& Beinecke, 2018). The $21^{\text {st }}$ century also brings with a set of new challenges and demands thus drastically changing the way leaders perform. Today's highly educated and skilful workforce requires flexible leadership (Holt \& Marques, 2012). Traditional leadership techniques such as transformational and transactional leadership are fast becoming obsolete; in their place today is visionary leadership which is more effective at raising employees' aspirations and tapping into their sentiments (Hayes, 2014). Leaders need to choose their words carefully to ensure clear information delivery, reinforce dyadic leader-member relationship (Luthra \& Dahiya, 2015), and guarantee shared understanding of organisational objectives (Murphy \& Clark, 2016). Effective leadership communication can lead to an effective organisation as it inspires and motivates employees (Naile \& Selesho, 2014). It also enables the leader to understand the employees' job situation and ensuing emotions, and thus provide the support needed. On top of that, effective communication facilitates the leader in establishing a cooperative relationship with a member built upon mutual trust. Ethical leadership values entail respect for the employees' wellbeing and the disposition to protect, support, improve and encourage them (Mahsud et al., 2010). A leader with such values is better able at developing and sustaining a cooperative relationship with his subordinates, which in turn can drive the formation of an exchange relationship.

Only a small number of existing studies have examined the relationship between empathetic leadership language and organizational effectiveness specifically in religious-based institutions such as Waqf institutions as well as other NPOs. Adnan et al., (2013) described Waqf institutions as NPOs managing endowment funds and properties in Muslim-majority countries. Studies on Waqf institutions typically emphasize the following aspects:

Table 1: Issues pertaining to Waqf property management

\begin{tabular}{lll}
\hline Themes & Effects & Scholar \\
\hline $\begin{array}{l}\text { Lack of } \\
\text { professionalism and } \\
\text { role ambiguity }\end{array}$ & Interruptions in the & (Abas \& Raji, 2018; Abdul Majid \\
& completion of istibdal. & \& Said, 2014; Audit, 2014d; \\
& Azmi et al., 2014; N. Hassan et \\
& $\begin{array}{l}\text { Failure to register property } \\
\text { Ownerships under the }\end{array}$ & $\begin{array}{l}\text { al., 2018; Ihsan \& Adnan, 2009; } \\
\text { Ismail et al., 2015; Mohd Puad }\end{array}$ \\
& $\begin{array}{l}\text { SIRCs. } \\
\text { Under-utilization of Waqf } \\
\text { properties. }\end{array}$ & \\
& & \\
&
\end{tabular}




\begin{tabular}{|c|c|c|}
\hline & $\begin{array}{l}\text { Failure to gazette Waqf } \\
\text { lands. } \\
\text { Encroachment. }\end{array}$ & \\
\hline $\begin{array}{l}\text { Encroachment of } \\
\text { Waqf lands }\end{array}$ & $\begin{array}{l}\text { Obstructions in developing } \\
\text { Waqf lands. } \\
\text { Failure to generate rental } \\
\text { revenues. } \\
\text { Owners not trusting Waqf } \\
\text { institutions. }\end{array}$ & $\begin{array}{l}\text { (Abdul Majid \& Said, 2014; } \\
\text { Abdul Rashid et al., 2015; Audit, } \\
\text { 2014a, 2014b, 2014c; Isamail et } \\
\text { al., 2015; Ismail et al., 2015; } \\
\text { Megat Abd Rahman et al., } \\
\text { 2006) }\end{array}$ \\
\hline $\begin{array}{l}\text { Lack of awareness } \\
\text { among Muslims }\end{array}$ & $\begin{array}{l}\text { Non-awareness about the } \\
\text { encroachment of Waqf } \\
\text { lands. } \\
\text { Non-awareness about } \\
\text { istibdal. }\end{array}$ & $\begin{array}{l}\text { (Ibrahim \& Ibrahim, 2013; } \\
\text { Isamail et al., 2015; Mohd Puad } \\
\text { et al., 2014) }\end{array}$ \\
\hline $\begin{array}{l}\text { Inefficient rental } \\
\text { system }\end{array}$ & $\begin{array}{l}\text { Rising rental arrears. } \\
\text { Unobtainability and non- } \\
\text { renewal of lease } \\
\text { agreements. } \\
\text { Non-payment of } \\
\text { commissions on leaseholds. } \\
\text { Very low rental rates, non- } \\
\text { revision of charges. } \\
\text { Ineffective or non-collection } \\
\text { of rental charges. }\end{array}$ & $\begin{array}{l}\text { (Abdul Majid \& Said, 2014; } \\
\text { Audit, 2014a, 2014b, 2014c, } \\
\text { 2014d;Mahmood \& Markom, } \\
\text { 2013;) }\end{array}$ \\
\hline $\begin{array}{l}\text { Data storage } \\
\text { problems }\end{array}$ & $\begin{array}{l}\text { Poor Waqf property record. } \\
\text { Untitled Waqf lands. } \\
\text { Encroachment. } \\
\text { Incomplete/non-updated } \\
\text { Waqf properties list. }\end{array}$ & $\begin{array}{l}\text { (Audit, 2014a, 2014c, 2014d; } \\
\text { Ismail et al., 2015; Rabitah } \\
\text { Harun et al., 2012) }\end{array}$ \\
\hline $\begin{array}{l}\text { No standard } \\
\text { procedures }\end{array}$ & $\begin{array}{l}\text { Encroachment. } \\
\text { Non-identification of land } \\
\text { ownership documents. }\end{array}$ & $\begin{array}{l}\text { (Audit, 2014c, 2014a; Ihsan \& } \\
\text { Adnan, 2009; Isamail et al., } \\
\text { 2015; Ismail et al., 2015; } \\
\text { Rabitah Harun et al., 2012) }\end{array}$ \\
\hline
\end{tabular}

The above shows that most NPOs fail to provide the needed information or public goods in justifying their purpose (Wallis \& Dollery, 2006). In Malaysia, for instance, there is a 
information asymmetry between NPOs and the donors (Zainon et al., 2012). On top of that, Malaysia does not possess a uniformed framework for NPOs unlike other countries such as the USA (Zainon et al., 2014) whilst the degree of its NPOs' transparency, accountability and good governance is not enforced by law (Ruhaya et al., 2012). According to Zainon et al. (2014), information disclosure for NPOs remains optional in Malaysia which indirectly affects the institutions' productivity and effectiveness as the lack of legal and legislative requirements leads to information asymmetry (Zainon et al., 2014). All this indicates the need for proper leadership practices and ethics to ensure the effective management of Waqf Institutions in Malaysia. Furthermore, Sharfizie et al., (2019a) also argue that in order to ensure the Waqf institution continues to be successful, the recognition of core competencies is strongly encouraged. Herman and Renz (1999) asserted that effective NPO management reflect proper management practices, leading to overall organizational effectiveness. In the case of religious-based NPOs such as Waqf institutions, the leadership reflects the practice of Islamic principles in the organization. Hence, leaders play an important part in driving ethical thinking and practice among the organizational members via effective interactions and clear communications of expectations in achieving shared objectives (Sharfizie et al., 2019a). Ethical leaders are empathetic and respectful towards others and their opinions, exhibiting personal warmth and sympathetic tendencies (Heres \& Lasthuizen, 2010) with the ability to understand and interpret behaviours. An empathetic leader hence can better understand and respond to the needs of his followers in such a way that improves their performances (Kock et al., 2019). A leader that can anticipate the needs of his followers also has the ability to determine the best management technique to improve their performance (Gavin et al., 1995). However, empathetic leaders need to have an affectionate disposition moderated via a leader-member exchange relationship, which makes it easier to achieve improved behavioural outcomes such as work effort.

This study intends to underline the relationship between empathetic leadership language and management effectiveness in the context of Waqf institutions as there are very few existing studies on the subject. This study also intends to test the moderating effect of leader-member exchange (LMX) in strengthening the relationship between *empathetic language and management effectiveness in Waqf institutions. Ultimately, this study aims to contribute to the development of NPOs especially Waqf institutions in terms of organizational leadership and management in the $21^{\text {st }}$ century. Dumas \& Beinecke, $(2018)$ asserted that $21^{\text {st }}$ century leaders need to have excellent interpersonal skills which are part of the emotional component essential for creating an inspiring vision that leads to the development of an atmosphere that encourages new meaning.

\section{Hypothesis Development}

Leaders who are able to understand the employees' emotional concerns are also better able at building a positive bond with them on top of displaying sincere concern about their emotional well-being (Mayfield \& Mayfield, 2010; Mayfield \& Mayfield, 2016) Leaders basically use empathetic language to show their gratitude for the employees' efforts (Mayfield et al., 2017) and to signal their acknowledgement of the employees' opinions and feedbacks (Alqahtani, 2015). This is one of the ways for showing appreciation and support towards the employees as human beings (Holmes, 2016). As such, empathetic leaders must also possess the trait of humility. This is in line with the Islamic values of humility which, in Islamic corporate culture, indicate the way the leader displays his appreciation of the employees' contributions (Khan et al., 2010). Humility is when the leader is willing to admit 
that his subordinates have better skills on top of granting the employees autonomy and support in order to earn their trust (Owens \& Hekman, 2013). Khan et al. (2010) highlighted the importance of trust, respect, integrity and faithfulness in a leader-employee relationship as per Islamic teaching. Allah SWT decrees in the Quran: "Whenever you judge between people, you should judge with (a sense of) justice" (Chapter 4: verse 58). This verse emphasizes the significance of respect and justice to all including in a leader-employee relationship. An employee who feels valued and appreciated by the leader is more likely to contribute and engage more within the organisation (Katz \& Kahn, 1979), ultimately improving organisational productivity and effectiveness. It is also the leader's role to communicate to the employees about the significance of their contribution in driving organizational success (Anitha, 2013). Based on the above, it is believed that empathetic language can boost employee motivation and morale towards producing and maintaining productivity. It is also highly impactful in recognizing good work (Mayfield \& Mayfield, 2007). Employees prefer to continue working in organisations with an ethical climate and effective employee-leader communication (Robbins \& Judge, 2012). Hypothesis 1 hence proposes that:

Hypothesis 1: Empathetic Language (EL) has a positive effect on the Management Effectiveness of Waqf properties in Waqf Institutions in Malaysia.

The quality of a leader-employee exchange relationship affects the leadership's effectiveness. Effective leaders typically have good interpersonal skills that influence the aptness of their behaviours and the efficient application of those behaviours on the employees (Mahsud et al., 2010). A highly empathetic leader has the ability to recognize significant behaviours in a relationship and use proper emotions and feelings to address employee needs (Haynie et al., 2018). It has been suggested that empathetic leaders can create high quality relationships that lead to positive employee and organisational outcomes (Hassan et al., 2013; Haynie et al., 2018).

Empathetic leaders have also been indicated to be able to identify employee satisfaction or dissatisfaction with regards to task delegation, rewards and benefits as well as the provision or lack of support (Mahsud et al., 2010). Employees who feel valued and appreciated have a greater tendency to contribute more and exhibit higher commitment. Haynie et al. (2018) suggested that the significant impacts contributed by the empathetic leader should be tailored to expedite the LMX interaction, thus leading to behavioural compliance. According to Mahsud et al. (2010), employees who see their leaders as empathetic will also have the impression of high quality LMX, as Sharfizie et al., (2019a) argue that a good LMX relationship can play a vital role in generating productivity in an organisation that in turn, can influence their behaviour. Hence, it can be concluded that greater LMX can strengthen the usage of empathetic language by the leader towards improving management effectiveness. Based on the discussion above, the following hypothesis is established:

Hypothesis 2: The effect of Empathetic Language on Management Effectiveness is strengthened by higher LMX than low LMX.

\section{Methods}

\section{Sample}

This study employs the census technique. As demonstrated in Table 2, this study has a sample size of 216 consisting of employees from Waqf institutions throughout Malaysia, which is considered small. According to Hair Jr. et al. (2014), the sample size is critical in all statistical analysis. The more complex and advanced the statistical analysis, the bigger the sample size 
required (Oke et al., 2012). As such, a number of scholars had suggested a sample size of at least 200 (Bagozzi, 2012; Harris \& Schaubroeck, 1990) to ensure the robustness of the structural equation modelling (Kline, 2011). Other researchers recommended a larger sample size ranging between 300 and 400 (Yuan et al., 2009) but less than 400 or else an elusive analysis occurs (Hair et al., 2014). Oke et al. (2012) proposed that the best sample size should be between 200 and 400 . This justifies the usage of the census technique in this research.

Table 2: Total Number of Permanent Employees

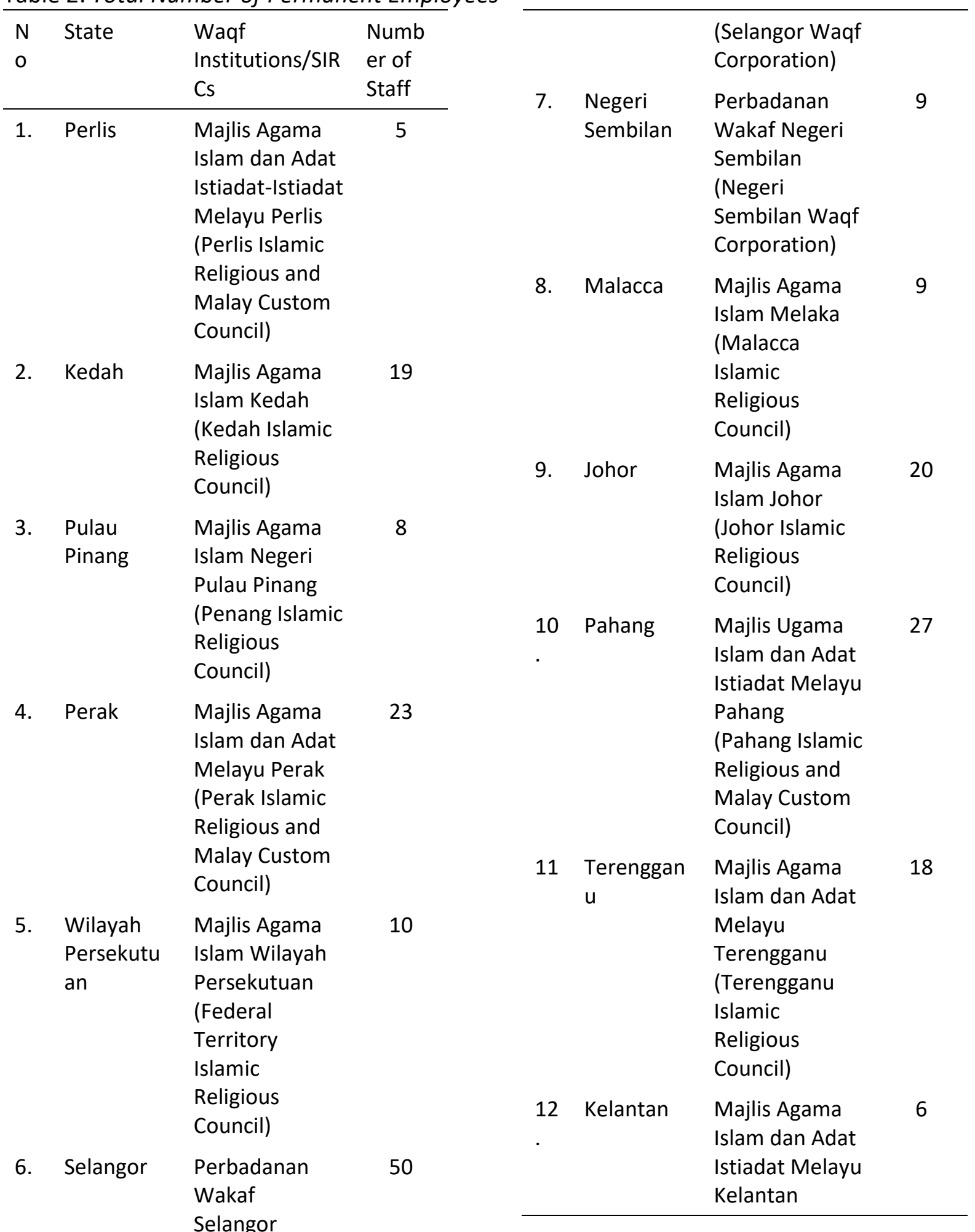




\begin{tabular}{|c|c|c|c|c|c|c|c|}
\hline \multirow{3}{*}{13} & \multirow{3}{*}{ Sabah } & \multicolumn{2}{|l|}{$\begin{array}{l}\text { (Kelantan } \\
\text { Islamic } \\
\text { Religious and } \\
\text { Malay Custom } \\
\text { Council) }\end{array}$} & 14 & Sarawak & $\begin{array}{l}\text { Tabung } \\
\text { Baitulmal } \\
\text { Sarawak } \\
\text { (Sarawak } \\
\text { Baitulmal } \\
\text { Fund) }\end{array}$ & 7 \\
\hline & & \multirow{2}{*}{$\begin{array}{l}\text { Perbadanan } \\
\text { Baitulmal } \\
\text { Sabah } \\
\text { (Sabah } \\
\text { Baitulmal } \\
\text { Corporation) }\end{array}$} & \multirow{2}{*}{5} & & & TOTAL & 216 \\
\hline & & & & & & & \\
\hline
\end{tabular}

Considering the small population of Waqf officers throughout Malaysia, the census technique is more appropriate as the sampling technique will cause the occurrence of an out-count of the elements and ultimately the failure to represent the actual targeted group of respondents (Daniel, 2012). As a matter of fact, owing to the serious issue of ineffective management in Waqf institutions throughout Malaysia, the credibility of this study's findings is expected to be based on a census instead of sampling.

\section{Measurement Items}

Empathetic language is measured via the empathetic dimension of the motivating language scale (J. Mayfield et al., 2017; Mayfield \& Mayfield, 2016) using a total of 5 items. This scale focuses on the way leaders demonstrate their emotional support and understanding. The effectiveness of Waqf property management in the Waqf institutions is measured using 23 items adapted from Siraj (2012). Finally, the construct of leader-member exchange (LMX) is used as the moderating variable for measuring the strengthening effects. $L M X$ is measured using 12 items adapted from Graen and Uhl-Bien (1995). This study employed a 7-point Likert scale whereby 1=Strongly Disagree and 7=Strongly Agree.

\section{Data Collection Procedures}

The self-administered questionnaires were disseminated to the 216 employees in Waqf institutions throughout all the states in Malaysia. The census method was employed considering the small number of populations. Questionnaire distribution was carried out using the drop-off technique i.e. by going to all the states in Peninsular Malaysia and meeting directly with the representative in each institution. The completed questionnaires from eight states (i.e. Johor, Malacca, Negeri Sembilan, Wilayah Persekutuan, Selangor, Perak, Kedah and Pahang) were self-collected by the researcher while those from the two Northern states (Pulau Pinang and Perlis) and the two East Coast states (Kelantan and Terengganu) were returned by air mail using the self-addressed return envelope that the researcher had provided along with the questionnaire. As for Sabah and Sarawak, an enumerator was assigned to distribute and collect the questionnaires. Earlier, the researcher had contacted the representatives of the institutions in the two states and requested them to cooperate with the enumerator.

\section{Data Analysis}

Due to the small sample size, this study benefits more from the usage of the PLS-SEM rather than the CB-SEM. Haenlein and Kaplan (2010) indicated the capability of the PLS-SEM to analyse 30-100 samples. Meanwhile, due to the non-parametric approach, PLS enables a non- 
normal data distribution (Hair Jr. et al. 2014), PLS is also the best choice for addressing the inadequate sample size and violation of normality assumption (Hair Jr et al., 2014; Urbach \& Ahlemann, 2010). Hair et al., (2018) argued that social science studies commonly fail to adhere to the normal data. Reinartz et al., (2009) further stated that with a limited dataset, CB-SEM may generate abnormal results as opposed to PLS-SEM which would demonstrate greater robustness. Hence, the best data analysis approach for this study is the PLS-SEM.

The non-response bias analysis was carried out by categorizing the respondents as early and late respondents. Both groups were then compared with each other in terms of their responses to the Likert scale questions using the Mann-Whitney-U-test. The results are presented in Table 3 which indicates an insignificant non-response bias, with values of not less than or equal to 0.05 . No differences were found in the responses of both groups; therefore, the findings can be generalized to the entire target population (Miller \& Smith, 1983 as cited in Lindner et al., 2001)

Table 3: Non-Responses Bias

\begin{tabular}{ll}
\hline & MEAN_EL \\
\hline Mann-Whitney U & 3065.500 \\
Asymp. Sig. (2-tailed) & .600 \\
\hline
\end{tabular}

Meanwhile, Podsakoff et al., (2003) indicated that the collection of data from a sole respondent using the same questionnaire can cause the occurrence of common method bias. As a procedural remedy, Harman's single factor test is utilised to detect the presence of common method bias in situations when a single factor is the predominant explanation of the variances (Podsakoff et al., 2003). In this current study, Harman's single factor test was carried out using the SPSS software. The first factor only explained 24.820 percent of the total variance, indicating the absence of common method bias.

A total of 216 questionnaires were disseminated to the respondents in all the states in Malaysia and a total of 162 responses were usable for the final analysis i.e. a return rate of 75 percent. Table 4 presents the respondents' demographic profile. Most of the respondents are aged between 21 to 30 years old (48.7\%) with a mean of 31.35 percent. A majority of the study population are males (53.7\%). Position wise, after omitting the three (3) missing data for this question, it was found that 34.6 percent of the respondents are non-supervisors, 30.9 percent are mid-level managers, 25.3 percent are first level managers, and 7.4 percent are supervisors. In terms of work tenure, 38.3 percent have served in the institution for over 6 years; 25.9 percent for 4 to 5 years; 27.8 percent for 1 to 3 years, and 8.0 percent for less than 12 months. A total of 39.5 percent have been serving under the same leader for 1 to 3 years and only 16.7 percent for less than 12 months.

Table 4: Respondents' Profile

\begin{tabular}{lccccc}
\hline & Frequency & Percent & Mean & Std Deviation \\
\hline Age & $21-30$ & 73 & 48.7 & & \\
& $31-40$ & 64 & 42.7 & 31.35 & 6.47 \\
$41-50$ & 12 & 8 & & \\
& $51-60$ & 1 & 0.7 & & \\
& & & &
\end{tabular}




\begin{tabular}{llcc}
\hline Gender & Male & 87 & 53.7 \\
\multirow{3}{*}{ Position } & Female & 75 & 46.3 \\
& Non-Supervisor & 56 & 34.6 \\
& $1^{\text {st }}$ Level Manager & 41 & 25.3 \\
& Supervisor & 12 & 7.4 \\
\multirow{4}{*}{ Organisation } & Mid-Level Manager & 50 & 30.9 \\
& Less than 12 months & 13 & 8.0 \\
& 1-3 years & 45 & 27.8 \\
Leader & 4-6 years & 42 & 25.9 \\
& More than 6 years & 62 & 38.3 \\
& Less than 12 months & 27 & 16.7 \\
& 1-3 years & 64 & 39.5 \\
& 4-6 years & 36 & 22.2 \\
& More than 6 years & 35 & 21.6 \\
\hline
\end{tabular}

\section{Measurement Model Assessment}

This section presents the measurement model assessment test results. As shown in Table 5, all the constructs have AVE values ranging from 0.503 to 0.56 i.e. exceeding the threshold value of 0.5 proposed by Byrne (2010); Hulland (1999). This indicates that the measurement model has adequate convergent validity.

Table 5: Items Loadings, Composite Reliability and the Average Variance Extracted for the Measurement Model

\begin{tabular}{ccccc}
\hline $\begin{array}{l}\text { Construct } \\
\text { /tem }\end{array}$ & $\begin{array}{c}\text { Loadi } \\
\text { ng }\end{array}$ & CA & CR & AVE \\
\hline $\begin{array}{l}\text { Empathetic } \\
\text { Language } \\
\text { (EL) }\end{array}$ & & $\begin{array}{c}\mathbf{0 . 8 0} \\
\mathbf{5}\end{array}$ & $\begin{array}{c}\mathbf{0 . 8} \\
\mathbf{6 3}\end{array}$ & $\mathbf{0 . 5 6}$ \\
\hline A1 & 0.85 & & & \\
A2 & 0.80 & & & \\
& 7 & & & \\
A3 & 0.77 & & & \\
& 2 & & & \\
A4 & 0.59 & & & \\
A5 & 0.69 & & & \\
& 5 & & & \\
\hline Leader- & & $\mathbf{0 . 8 9}$ & $\mathbf{0 . 9}$ & $\mathbf{0 . 5 0}$ \\
Member & & $\mathbf{2}$ & $\mathbf{1}$ & $\mathbf{3}$ \\
\hline
\end{tabular}

\begin{tabular}{cc}
\hline $\begin{array}{l}\text { Exchange } \\
\text { (LMX) }\end{array}$ & \\
\hline B1 & 0.72 \\
& 1 \\
B2 & 0.65 \\
& 9 \\
B3 & 0.68 \\
& 6 \\
B4 & 0.81 \\
& 2 \\
B5 & 0.67 \\
B6 & 0.71 \\
& 2 \\
B7 & 0.67 \\
& 1 \\
\hline
\end{tabular}


INTERNATIONAL JOURNAL OF ACADEMIC RESEARCH IN BUSINESS AND SOCIAL SCIENCES Vol. 10, No. 10, 2020, E-ISSN: 2222-6990 @ 2020 HRMARS

\begin{tabular}{|c|c|c|c|c|}
\hline B8 & $\begin{array}{c}0.73 \\
5\end{array}$ & & & \\
\hline B9 & $\begin{array}{c}0.76 \\
6\end{array}$ & & & \\
\hline B10 & $\begin{array}{c}0.64 \\
3\end{array}$ & & & \\
\hline $\begin{array}{l}\text { Management } \\
\text { Effectiveness } \\
\text { (ME) }\end{array}$ & & $\begin{array}{c}0.93 \\
9\end{array}$ & $\begin{array}{l}0.9 \\
46\end{array}$ & $\begin{array}{c}0.51 \\
1\end{array}$ \\
\hline $\mathrm{C} 1$ & $\begin{array}{c}0.69 \\
5\end{array}$ & & & \\
\hline $\mathrm{C} 2$ & $\begin{array}{c}0.68 \\
2\end{array}$ & & & \\
\hline C3 & $\begin{array}{c}0.71 \\
6\end{array}$ & & & \\
\hline $\mathrm{C} 4$ & $\begin{array}{c}0.67 \\
1\end{array}$ & & & \\
\hline $\mathrm{C} 5$ & $\begin{array}{c}0.58 \\
7\end{array}$ & & & \\
\hline C6 & $\begin{array}{c}0.71 \\
3\end{array}$ & & & \\
\hline $\mathrm{C7}$ & $\begin{array}{c}0.64 \\
3\end{array}$ & & & \\
\hline C8 & 0.73 & & & \\
\hline C9 & $\begin{array}{c}0.77 \\
1\end{array}$ & & & \\
\hline C10 & $\begin{array}{c}0.86 \\
5\end{array}$ & & & \\
\hline D14 & $\begin{array}{c}0.83 \\
1\end{array}$ & & & \\
\hline D15 & $\begin{array}{c}0.86 \\
9\end{array}$ & & & \\
\hline D16 & $\begin{array}{c}0.75 \\
5\end{array}$ & & & \\
\hline D17 & $\begin{array}{c}0.65 \\
2\end{array}$ & & & \\
\hline D18 & $\begin{array}{c}0.65 \\
4\end{array}$ & & & \\
\hline D19 & $\begin{array}{c}0.57 \\
2\end{array}$ & & & \\
\hline
\end{tabular}

\begin{tabular}{lc}
\hline D22 & 0.65 \\
& 8 \\
\hline
\end{tabular}


Next is the assessment for discriminant validity via HTMT. As the Fornell and Larcker (1981) criterion for evaluating discriminant validity has been greatly debated, this study uses the HeterotraitMonotrait (HTMT) ratio proposed by Henseler et al., (2015) which examines the ratio of the correlation within the constructs to the correlation between the constructs (Ramayah et al., 2018). In assessing the HTMT inference, Henseler et al. (2015) suggested the value of 1 to indicate a lack of discriminant validity (Ramayah et al., 2018). As shown in Table 6, all the values meet the HTMT criterion whereby the confidence interval for all the constructs does not indicate a value of 1 (Ramayah et al., 2018). Hence, discriminant validity is verified for the measurement model.

Table 6: Discriminant Validity using HTMT

\begin{tabular}{llll}
\hline & EL & LMX & ME \\
\hline EL & & & \\
LMX & 0.221 & & \\
ME & 0.460 & 0.307 & \\
\hline
\end{tabular}

\section{Results}

Next is the structural model assessment. The significance level was measured by generating the tstatistics using the Smart PLS bootstrapping function. Before assessing the structural model, there is a crucial need to address any possible collinearity issue. Despite fulfilling the requirements for discriminant validity, the presence of lateral collinearity can result in misleading findings (Ramayah et al., 2018). Hence, each set of the predictor construct must be evaluated individually for each subset of the structural model. The results of the lateral collinearity test are shown in Table 7. All the Inner VIF values for the independent variable (Empathetic Language) are less than five indicating the absence of any lateral multicollinearity in this study (Hair Jr et al., 2014). Based on the path coefficient assessment results shown in Table 7 , it is found that empathetic language (EL) $(\beta=0.154, p>0.05)$ has a positive but non-significant effect. Therefore, $\mathrm{H} 1$ is not supported. The $\mathrm{R}^{2}$ value is 0.416 which is higher than the 0.26 threshold proposed by Cohen (1988), suggesting that the model is substantial. Next is the evaluation of the effect size $\left(f^{2}\right)$ i.e. to identify the impact size of the exogenous construct on the endogenous construct (small, medium or large) (Hair Jr et al., 2014). According to Ramayah et al. (2018), the $p$ value only indicates the existence of an effect, but not its size. Therefore, the identification of both the effect size and $p$ value is crucial. The effect size is measured based on the guideline provided by Cohen (1988) which states that a value of 0.02 has a small effect, 0.15 a medium effect and 0.35 a large effect. The $f^{2}$ result revealed that empathetic language (EL) $(0.030)$ has a small effect in generating the $\mathrm{R}^{2}$ for management effectiveness (ME).

Meanwhile, the model's predictive relevance $\left(Q^{2}\right)$ is assessed using the blindfolding procedure. Hair et al., (2017) suggested that a $Q^{2}$ greater than 0 indicates that the model has predictive relevance for a given endogenous construct. In this current study, the $\mathrm{Q}^{2}$ value is 0.192 suggesting adequate predictive relevance for the model. Table 7 presents the summary of the hypothesis testing in relation to the direct effects. 
INTERNATIONAL JOURNAL OF ACADEMIC RESEARCH IN BUSINESS AND SOCIAL SCIENCES

Vol. 10, No. 10, 2020, E-ISSN: 2222-6990 @ 2020 HRMARS

Table 7

Summary of the Hypothesis Testing Related to Direct Effect

\begin{tabular}{llllllll}
\hline Hypothesis & $\begin{array}{l}\text { Hypothesis } \\
\text { Path }\end{array}$ & $\begin{array}{l}\text { Standard } \\
\text { Beta }\end{array}$ & t-value & p-value & $f^{2}$ & VIF & Results \\
\hline $\mathrm{H} 1$ & $\mathrm{EL} \longrightarrow$ & 0.154 & 1.406 & 0.080 & 0.030 & 1.349 & $\begin{array}{l}\text { Not } \\
\text { Supported }\end{array}$ \\
\hline
\end{tabular}

\section{Moderating Effect}

The next research question seeks to determine the moderating effect in the model. Ramayah et al. (2018) defined moderating effect (d) as the third variable that influences the correlation between the independent variable and the dependent variable. According to the authors, an interaction occurs between the moderator and the predictor variable resulting in an effect on the dependent variable. In this current study, the Product Indicator Approach is employed to measure the interaction term (Moderator Analysis). This is based on the suggestion of Ramayah et al. (2018) who stated that the product indicator approach would be the best if all the constructs (IV and Moderator) are reflective. The $\mathrm{R}^{2}$ change is significant in measuring the moderator. On the main effect model, the $\mathrm{R}^{2}$ shows a value of 0.416 whilst following the interaction with the effect model, the $R^{2}$ shows a value of 0.443 i.e. an $R^{2}$ change of $2.7 \%$ (additional variance) (see Figure 4.2 ). The subsequent step entails the effect size $\mathrm{f}^{2}$ calculation using the formula below:

$\mathrm{f}^{2}=\frac{\mathrm{R}^{2} \text { included moderator }-\mathrm{R}^{2} \text { excluded moderator }}{1-\mathrm{R}^{2} \text { included moderator }}$
$=\frac{0.443-0.416}{1-0.443}$
$=\mathbf{0 . 0 4 8}$

Based on Cohen's (1988) guideline for $\mathbf{f}^{\mathbf{2}}$ interpretation, the value of 0.048 is deemed as a small effect size. According to Chin et al., (2003) a small effect size $\mathbf{f}^{2}$ does not essentially indicate a negligible underlying moderator effect: "Even a small interaction effect can be meaningful under extreme moderating conditions, if the resulting beta changes are meaningful, then it is important to take these conditions into account" (Chin et al., 2003, p. 211). Despite reporting a beta coefficient of EL*LM (0.071), there is still a need to determine the statistical significance of the beta. The subsequent step in testing the interaction involves the $t$-value derivation via the bootstrapping procedures.

Table 8 shows the outcomes of the hypothesis testing in relation to the moderating effect. $\mathrm{H} 2$ which proposed that the impact of empathetic language $(E L)(\beta=-0.171, p<0.05)$ on management effectiveness (ME) is strengthened by high LMX is supported. Therefore, a high LMX strengthens the path from EL to ME.

Table 8: Summary of the Hypothesis Testing Related to Moderating Effect

\begin{tabular}{lllllll}
\hline Hypothesis & Hypothesis Path & Standard Beta & t-value & $p$-value & $\mathrm{f}^{2}$ & Results \\
\hline H2 & EL*LMX-ME & -0.071 & 2.300 & 0.011 & 0.041 & Supported \\
\hline
\end{tabular}


INTERNATIONAL JOURNAL OF ACADEMIC RESEARCH IN BUSINESS AND SOCIAL SCIENCES Vol. 10, No. 10, 2020, E-ISSN: 2222-6990 @ 2020 HRMARS

\section{Conclusion and Discussion}

Based on the results derived, empathetic language (EL) $(\beta=0.154, p>0.05)$ is determined to have an insignificant effect on the management effectiveness of Waqf institutions. Interestingly, the results suggest that culture has an effect on the language used by the leader. In the study by Madlock and Sexton (2015), the organisational culture prevalent in Mexican firms renders the employees to be less affected by instructions delivered using empathetic language. Similarly, the findings of this current study also suggest that empathetic language has no effect in creating positive work outcomes owing to the existing organisational culture in Waqf institutions in Malaysia. Gentry et al., (2016) state that Malaysia practices a high power distance culture and according to Hofstede et al., (2010), high power distance culture is "the extent to which less powerful members of institutions and organizations within a country expect and accept that power is distributed unequally" (p.61). In an organisation with a high power distance culture, the employees identify organisational hierarchy as an indication of power inequality between those in higher level and lower level positions (Hofstede et al., 2010). In such conditions, the employees are inclined to act according to their leader's instructions and directions (Duran-brizuela et al., 2016) and abstain from going against those directives for fear of being deemed as disrespectful (Puni \& Anlesinya, 2017). Despite the findings by Gentry et al. (2016) of the significant and positive effect of empathetic language in improving the performance of high power distance organisations, this culture inculcates the notion that employees must respect their leaders and that leaders expect compliance from the employees. As such, the employees typically abstain from participating in any decision-making process as they prefer to remain submissive (Erkutlu \& Chafra, 2016). As the employees continue to become highly dependent on their leader, a huge leader-employee gap is thus created (Hofstede et al., 2010). The discussions above justify the reason as to why empathetic language is not applicable for employees in Waqf institutions in Malaysia.

The results also show that the correlation between empathetic language (EL) and management effectiveness (ME) $(\beta=-0.171, p<0.05)$ is significantly strengthened by a higher LMX rather than a low LMX. Figure 1 shows this interaction i.e. the effect of empathetic language (EL) on management effectiveness (ME) is high and strengthened when the $L M X$ is high, thus supporting Hypothesis 2. This result is consistent with that of Hassan et al. (2013) and Haynie et al. (2018) which suggest that empathetic language use by leaders produces better leader-employee relationship which in turn creates improved employee performance. Although there is no direct relationship between

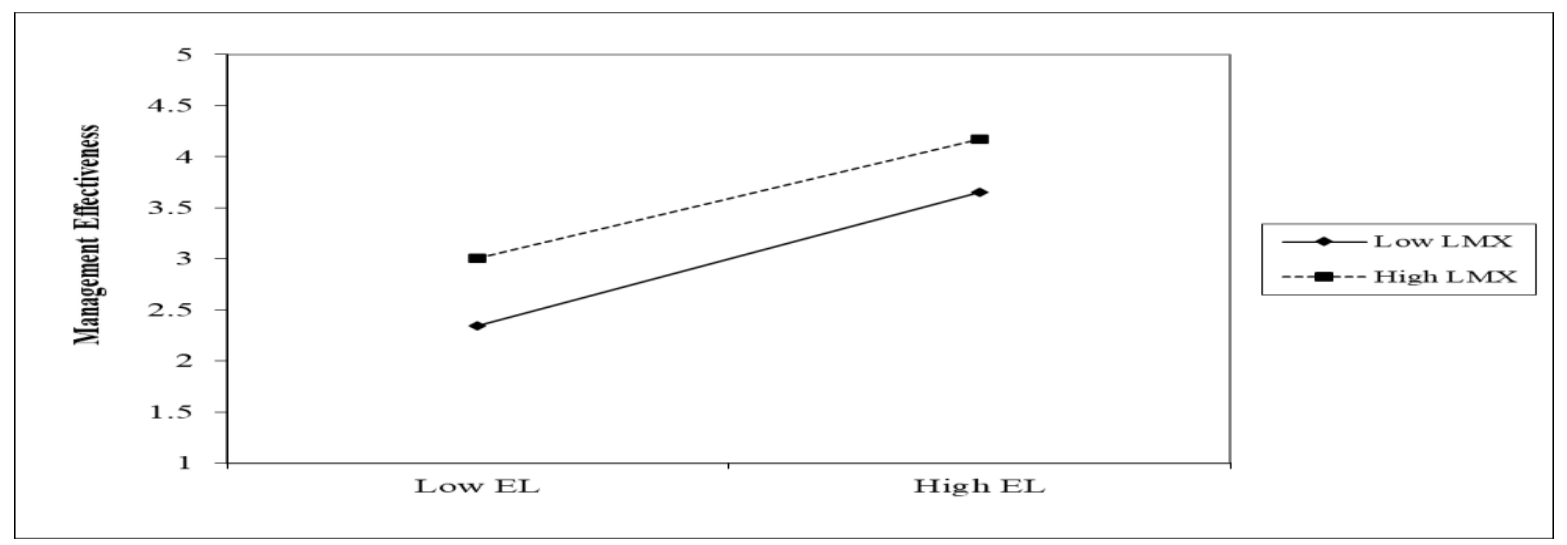

empathetic language (EL) and management effectiveness (ME), LMX is found to enhance leadership Figure.1. Interactive Effect of Empathetic Language (EL) and LMX on ME 
communication among the employees of the Waqf institutions. And although empathetic language is indicated to be inapt in creating effectiveness in high power distance countries such as Malaysia, the leader can take advantage of the employees' perception of their competence and utilize it to create employee compliance and commitment so as to achieve the goals and objectives of the organisation (Lo et al., 2010). This in turn creates greater compromise among the employees leading them to accept the effective utilisation of empathetic language. The Social Exchange Theory (SET) by Blau, (1964) explains these findings as such: employees tend to demonstrate higher commitment and deliver greater contributions when there is a perception that their leader provides them with practical and rightful material sources, information and support. The higher this perception, the greater the LMX would be between both parties. In general, the results show that the path from empathetic language (EL) to management effectiveness (ME) depends upon the mutual leaderemployee relationship, of which impact is strengthened by a higher LMX rather than a low LMX. As such, employees need to establish a high reciprocity with their leader in order to achieve management effectiveness. A strong reciprocal relationship facilitates the usage of empathetic language in driving management effectiveness.

With these findings, Waqf institution leaders can establish a multitude of language approaches so as to generate positive organisational outcomes. Interpersonal exchanges have been proposed as a viable approach in driving employee performance. The scale employed in this study could be used as a mechanism for identifying flaws in the prevailing communication skills of the leaders. Using the scale, leaders can attain in-depth insight on how management effectiveness can be achieved via the usage of suitable leadership language. Additionally, the leader-member exchange (LMX) scale can also be used to determine factors that drive reciprocal exchanges between the two parties. Credibility and leader communication skills are another two aspects highlighted in this study. In Islamic-based organisations, the elements of trust and faith are of utmost importance. Therefore, the leaders need to walk the talk and lead by example in the effort to materialize positive individual and organisational outcomes.

As a conclusion, demonstrating empathetic is a vital aspect of leadership success, and it also enhances interpersonal relations in general and can contribute to more effective communication and better outcomes for both workers and organisations.

\section{References}

Abas, F. N., \& Raji, F. (2018). Factors Contributing to Inefficient Management and Maintenance of Waqf Properties: A Literature Review. International Journal of Islamic and Civilizational Studies, 5(3), 53-67.

Abdul Majid, R., \& Said, R. (2014). Permasalahan Pengurusan Hartanah Wakaf di Malaysia. International Surveying Reserach Journal, 4(1), 29-43.

Abdul Rashid, R., Hussin, R., \& Yaakub, N. I. (2015). Pencerobohan Tanah Wakaf dari Aspek Perundangan Negara. International Conferences on Waqf 2015 (ICW 2105).

Adnan, N. S., Kamaluddi, A., \& Kasim, N. (2013). Intellectual capital in religious organisations: Malaysian zakat institutions perspective. Middle East Journal of Scientific Research, 16(3), 368377. https://doi.org/10.5829/idosi.mejsr.2013.16.03.11092

Alqahtani, A. A. (2015). Teachers' Perceptions of Principals' Motivating Language and Public School Climates in Kuwait. Management in Education, 29(3), 125-131.

https://doi.org/10.1177/0892020615584104 
INTERNATIONAL JOURNAL OF ACADEMIC RESEARCH IN BUSINESS AND SOCIAL SCIENCES Vol. 10, No. 10, 2020, E-ISSN: 2222-6990 @ 2020 HRMARS

Anitha, J. (2013). Determinants of employee engagement and their impact on employee performance. International Journal of Productivity and Performance Management, 63(3), 308323. https://doi.org/10.1108/IJPPM-01-2013-0008

Audit, J. (2014a). Laporan Ketua Audir Negara Tahun 2014- Aktiviti Jabatan/Agensi dan Pengurusan Syarikat Kerajaan NEGERI JOHOR. https://www.audit.gov.my/index.php/90-laporan-ketuaaudit-negara/state/550-negeri-2014-siri-3

Audit, J. (2014b). Laporan Ketua Audir Negara Tahun 2014- Aktiviti Jabatan/Agensi dan Pengurusan Syarikat Kerajaan NEGERI MELAKA. https://www.audit.gov.my/index.php/90-laporan-ketuaaudit-negara/state/550-negeri-2014-siri-3

Audit, J. (2014c). Laporan Ketua Audir Negara Tahun 2014- Aktiviti Jabatan/Agensi dan Pengurusan Syarikat Kerajaan NEGERI SELANGOR. https://www.audit.gov.my/index.php/90-laporan-ketuaaudit-negara/state/550-negeri-2014-siri-3

Audit, J. (2014d). Laporan Ketua Audir Negara Tahun 2014- Aktiviti Jabatan/Agensi dan Pengurusan Syarikat Kerajaan NEGERI SEMBILAN. https://www.audit.gov.my/index.php/90-laporan-ketuaaudit-negara/state/550-negeri-2014-siri-3

Azmi, N. F., Muhamad, S. F., \& Kamarudin, M. K. (2014). Challenges in Developing the Waqf Properties : The Study on State Islamic Religious Council in Kelantan. International Journal of Management Sciences, 3(7), 487-490.

Bagozzi, R. P., \& Y. Y. (2012). Specification, Evaluation, and Interpretation of Structural Equation Models. Journal of the Academy of Marketing Science, 40(1), 8-34. https://doi.org/10.1007/s11747-011-0278-x

Blau, P. M. (1989). Exchange and power in social life. This Week's Citation Classic, 352. https://doi.org/10.2307/2091154

Byrne, B. M. (2010). Structural Equation Modeling with AMOS. Routledge, Taylor \& Francis Group.

Chin, W. W., Marcolin, B. L., \& Newsted, P. R. (2003). A Partial Least Squares Latent Variable Modeling Approach for Measuring Interaction Effects: Results from a Monte Carlo Simulation Study and an Electronic-Mail Emotion/Adoption Study. Information System Research, 14, 189217994. https://doi.org/10.1126/science.143.3610.994

Cohen, J. (1988). Statistical Power Analysis for the Behavioral Sciences (2nd New ed). Taylor \& Francis Inc.

Daniel, J. (2012). Choosing Between Taking a Census and Sampling. SAGE Publications, Inc. https://doi.org/https://dx.doi.org/10.4135/9781452272047

Dumas, C., \& Beinecke, R. H. (2018). Change leadership in the 21st century. Journal of Organizational Change Management. https://doi.org/10.1108/JOCM-02-2017-0042

Duran-brizuela, R., Brenes-leiva, G., Solis-salazar, M., \& Torres-carballo, F. (2016). Effects of Power Distance Diversity within Workgroups on Work Role Performance and Organizational Citizenship Behavior. Tecnologia En Marcha, 29(2), 63-76.

Erkutlu, H., \& Chafra, J. (2016). Impact of behavioral integrity on organizational identification: The moderating roles of power distance and organizational politics. Management Research Review, 39(6), 672-691. https://doi.org/10.1108/MRR-01-2015-0011

Fornell, C., \& Larcker, D. F. (1981). Evaluating Structural Equation Models with Unobservable Variables and Measurement Error. Journal of Marketing Research, 18(1), 39-50.

Gavin, M. B., Stephen G, G., \& Fairhurst, G. T. (1995). Managerial Contol Strategies for Poor Performance over Time and the Impact on Subordinate Reactions. Organizational Behavior and 
INTERNATIONAL JOURNAL OF ACADEMIC RESEARCH IN BUSINESS AND SOCIAL SCIENCES Vol. 10, No. 10, 2020, E-ISSN: 2222-6990 @ 2020 HRMARS

Human Process, 63(2), 207-221.

Gentry, W. A., Weber, T. J., \& Sadri, G. (2016). Empathy in the Workplace: A Tool for Effective Leadership (White Paper Centre for Creative Leadership). https://cclinnovation.org/wpcontent/uploads/2020/03/empathyintheworkplace.pdf

Graen, G., \& Uhl-Bien, M. (1995). Relationship based approac to leadership; Development of Leader-Member Exchange (LMX) theory of Leadership over 25 years. Leadership Quarterly, 6(2)(Lmx), 219-247. https://doi.org/10.1016/1048-9843(95)90036-5

Haenlein, M., \& Kaplan, A. M. (2010). A Beginner's Guide to Partial Least Squares. Understanding Statistics, 3(4), 283-297. https://doi.org/10.1207/s15328031us0304

Hair, J., Hult, G. T. M., Ringle, C. M., \& Sarstedt, M. (2017). A Primer on Partial Least Squares Structural Equation Modeling (PLS-SEM). Thousand Oaks. SAGE Publications, Inc.

Hair, J., Risher, J. J., Sarstedt, M., \& Ringle, C. M. (2018). When to use and how to report the results of PLS-SEM. European Business Review. https://doi.org/https://doi.org/10.1108/EBR-11-20180203

Hair Jr, J. F., Black, W. C., Babin, B. J., \& Anderson, R. E. (2014). Multivariate Data Analysis. Pearson New International Edition.

Harris, M. M., \& Schaubroeck, J. (1990). Confirmatory modelling in organizational behaviour/Human resource management: issues and applications. Journal of Management, 16(2), 337-360.

Hassan, N., Abdul-Rahman, A., \& Yazid, Z. (2018). Developing a New Framework of Waqf Management Developing a New Framework of Waqf Management. International Journal of Academic Research in Business \& Social Sciences, 8(2), 287-305. https://doi.org/10.6007/IJARBSS/v8-i2/3872

Hassan, S., Mahsud, R., Yukl, G., \& Prussia, G. E. (2013). Ethical and empowering leadership and leader effectiveness. Journal of Managerial Psychology, 28(2), 133-146. https://doi.org/10.1108/02683941311300252

Hayes, J. (2014). The Theory and Practice of Change Management (Fourth Edi). PALGRAVE MACMILLAN.

Haynie, J. J., Baur, J., Harris, J. N., Harris, S. G., \& Moates, K. N. (2018). When Caring Leaders Are Constrained : The Impact of LMX Differentiation on Leader Empathic Concern in Predicting Discretionary Work Behaviors. Journal of Leadership \& Organizational Studies, 1-13. https://doi.org/10.1177/1548051818767394

Henseler, J., Ringle, C. M., \& Sarstedt, M. (2015). A New Criterion for Assessing Discriminant Validity in Variance-based A new criterion for assessing discriminant validity in variance-based structural equation modeling. Journal of Academic Marketing Science, 43, 115-135. https://doi.org/10.1007/s11747-014-0403-8

Heres, L., \& Lasthuizen, K. (2010). Ethical Leadership : a Variform Universal Phenomenon Ethical Leadership : a Variform Universal Phenomenon. Governance An International Journal Of Policy And Administration, August, 7-9.

Herman, R. D., \& Renz, D. O. (1999). Theses on nonprofit organizational effectiveness. Nonprofit and Voluntary Sector Quarterly, 28(2), 107-126. https://doi.org/10.1177/0899764099282001

Hofstede, G., Hofstede, G. J., \& Minkov, M. (2010). Cultures and Organizations. Mc Graw Hills.

Holmes, W. T. (2016). Motivating language theory: antecedent variables - critical to both the success of leaders and organizations. Development and Learning in Organizations: An International Journal, 30(3), 13-16. https://doi.org/10.1108/DLO-10-2015-0085 
INTERNATIONAL JOURNAL OF ACADEMIC RESEARCH IN BUSINESS AND SOCIAL SCIENCES

Vol. 10, No. 10, 2020, E-ISSN: 2222-6990 @ 2020 HRMARS

Holt, S., \& Marques, J. (2012). Empathy in Leadership: Appropriate or Misplaced? An Empirical Study on a Topic That is Asking for Attention. Journal of Business Ethics, July, 95-105. https://doi.org/10.1007/s10551-011-0951-5

Hulland, J. (1999). Use Of Partial Least Squares ( PLS ) In Strategic Management Research : A Review Of Four Recent Studies. Strategic Management Journal, 20, 195-204.

Ibrahim, D., \& Ibrahim, H. (2013). Revival of Waqf Properties in Malaysia. Proceeding of the 5th Islamic Economics System Conference (IECONS 2013), 13-24.

Ihsan, H., \& Adnan, M. A. (2009). Waqf Accounting and The Construction of Accountability. Genuine Publications and Media Pvt. Ltd, New Delhi.

http://www.academia.edu/504496/Waqf_Accounting_and_The_Construction of_Accountability.

Isamail, M. Z., Rosele, M. I., \& Anuar, M. (2015). Pemerkasaan Wakaf di Malaysia: Satu Sorotan. Labuan E-Journal of Muamalat and Society, 9, 1-13.

Ismail, C. Z., Salim, N. J., \& Ahmad Hanafiah, N. J. (2015). Administration and management of waqf land in Malaysia: Issues and solutions. Mediterraen Journal of Social Sciences, 6(4), 613-620. https://doi.org/10.5901/mjss.2015.v6n4s2p613

Kahf, M. (2003). The Role of Waqf In Improving The Ummah Welfare. Presented to the International Seminar on "Waqf as a Private Legal Body" Organized by the Islamic University of North Sumatra, Medan, Indonesia Jan. 6-7, 2003, 1-26.

Katz, D., \& Kahn, R. L. (1979). The Social Psychology of Organizations. John Wiley \& Sons Ltd; International edition.

Khan, B., Farooq, A., \& Hussain, Z. (2010). Human resource management : an Islamic perspective. Asia-Pacific Journal of Business Administration, 2(1), 17-34. https://doi.org/10.1108/17574321011037558

Kline, R. B. (2011). Principles and Practices of Structural Equation Modelling (Third Edit). THE GUILFORD PRESS.

Kock, N., Mayfield, M., Mayfield, J., Sexton, S., \& Garza, L. M. D. La. (2019). Empathetic Leadership : How Leader Emotional Support and Understanding Influences Follower Performance. Journal of Leadership \& Organizational Studies, 26(2), 217-236. https://doi.org/10.1177/1548051818806290

Kolb, R. W. (2018). Nonprofit Organizations. In The SAGE Encyclopedia of Business Ethics and Society (pp. 2491-2495). SAGE Publications, Inc. https://doi.org/10.4135/9781483381503.n854

Lindner, J. R., Murphy, T. H., \& Briers, G. E. (2001). Handling Non Responses in Social Science Research. Journal of Agricultural Education, 42(4), 44-53.

Lo, M., Ramayah, T., Min, H. W., \& Songan, P. (2010). The relationship between leadership styles and organizational commitment in Malaysia : role of leader - member exchange. Asia Pacific Business Review, 16(1-2), 79-103. https://doi.org/10.1080/13602380903355676

Luthra, A., \& Dahiya, R. (2015). Effective Leadership is all About Communicating Effectively : Connecting Leadership and Communication. International Journal of Management \& Business Studies, 5(3), 43-48.

Madlock, P. E., \& Sexton, S. (2015). An Application of Motivating Language Theory in Mexican Organizations. Journal of Business Communication, 52(3), 255-272. https://doi.org/10.1177/2329488415572783

Mahmood, N. A., \& Markom, R. (2013). Transformasi Institusi Pelaksana Wakaf : Kes Waqaf An-Nur 
INTERNATIONAL JOURNAL OF ACADEMIC RESEARCH IN BUSINESS AND SOCIAL SCIENCES Vol. 10, No. 10, 2020, E-ISSN: $2222-6990$ @ 2020 HRMARS

Corporation. Seminar Waqf Iqlimi, 331-344.

Mahsud, R., Yukl, G., \& Prussia, G. (2010). Leader empathy, ethical leadership , and relationsoriented behaviors as antecedents of leader-member exchange quality. Journal of Managerial Psychology, 25(6), 561-577. https://doi.org/10.1108/02683941011056932

Mayfield, J., \& Mayfield, M. (2007). The Effects of Leader Communication on a Worker' s Intent to Stay : An Investigation Using Structural Equation Modeling. Human Performance, 20(2), 85102. https://doi.org/10.1080/08959280701332018

Mayfield, J., \& Mayfield, M. (2010). Leader-level influence on motivating language. Competitiveness Review, 20(5), 407-422. https://doi.org/10.1108/10595421011080788

Mayfield, J., Mayfield, M., \& Neck, C. P. (2017). Speaking to the Self: How Motivating Language Links With Self-Leadership. International Journal of Business Communication, 1-24.

https://doi.org/10.1177/2329488417731861

Mayfield, M., \& Mayfield, J. (2016). The Effects of Leader Motivating Language Use on Employee Decision Making. International Journal of Business Communication, 53(4), 465-484. https://doi.org/10.1177/2329488415572787

Men, L. R. (2015). The Role of Ethical Leadership in Internal Communication: Influences on Communication Symmetry, Leader Credibility, and Employee Engagement. Journal Public Relations, 9, 1-22.

Arshad, M. N., \& Haneef, M. A. (2016). Third Sector Socio-Economic Models : How Waqf Fits In ? Institutions and Economics, 8(2), 75-93.

Puad, M. N. A., Rafdi, J. N., \& Shahar, W. S. S. (2014). Issues and Challenges of Waqf Instruments: A Case Study in MAIS. E-Proceedings of the Conference on Management and Muamalah, May, 978-983. https://doi.org/10.1007/s13398-014-0173-7.2

Morris, M. H., Kuratko, D. F., \& Covin, J. G. (2011). Corporate Entrepreneurship \& Innovation (3rd Editio). South Western.

Murphy, C., \& Clark, J. R. (2016). Picture this : How the language of leaders drives. Organizational Dynamics, 45(2), 139-146. https://doi.org/10.1016/j.orgdyn.2016.02.008

Naile, I., \& Selesho, J. M. (2014). The Role of Leadership in Employee Motivation. 5(3), 175-182. https://doi.org/10.5901/mjss.2014.v5n3p175

Oke, A. E., Ogunsami, D. R., \& Ogunlana, S. (2012). Establishing a Common Ground for the Use of Structural Equation Modelling for Construction Related Research Studies. Australasian Journal of Construction Economics and Building, 12(3), 89-94.

Othman, R., Ali, N., Omar, N., \& Abdul Rahman, R. (2012). Practical Challenges in Managing NonProfit Organizations ( NPO ): Tales from Two Neighboring Countries. International Bulletin of Business Administration, 13(13), 6-23.

Owens, B. P., \& Hekman, D. R. (2013). How Does Leader Humility Influence Team Performance? Exploring the Mechanisms of Contagion and Collective Promotion Focus. Academy of Management Journal, 1-55.

Pervez, S. (2006). Leadership in Organizations: A Comparative Study of Profit and Non-Profit Organizations [Master Award, University of Kalmar, Sweden]. https://doi.org/10.1108/ijm.2006.01627aaa.001

Podsakoff, P. M., Mackenzie, S. B., Lee, J., \& Podsakoff, N. P. (2003). Common Method Biases in Behavioral Research : A Critical Review of the Literature and Recommended Remedies. Journal of Applied Psychology, 88(5), 879-903. https://doi.org/10.1037/0021-9010.88.5.879 
INTERNATIONAL JOURNAL OF ACADEMIC RESEARCH IN BUSINESS AND SOCIAL SCIENCES Vol. 10, No. 10, 2020, E-ISSN: 2222-6990 @ 2020 HRMARS

Puni, A., \& Anlesinya, A. (2017). Whistleblowing Propensity in Power Distance Societies. Journal of Global Responsibility, 8(2), 212-224. https://doi.org/10.1108/JGR-02-2017-0005

Harun, R., Isa, Z. M., \& Ali, N. (2012). Preliminary Findings on Waqf Management Practices among Selected Muslim Countries. International Conference on Economics Marketing and Management, 28, 117-120.

Ramayah, T., Jacky, C., Chuah, F., Hiram, T., \& Ali, M. (2018). Partial Least Squares Structural Equation Modelling (PLS-SEM) using SmartPLS - An updated and practical guide to statistical analysis. Pearson Education Inc.

Hasan, R., \& Siraj, S. A. (2017). Toward Developing a Model of Stakeholder Trust in Waqf Institutions. Is/amic Economic Studies, 25, 85-110. https://doi.org/10.12816/0036187

Reinartz, W., Haenlein, M., \& Henseler, J. (2009). An empirical comparison of the efficacy of covariance-based and variance-based SEM. International Journal of Research in Marketing, 26(4), 332-344. https://doi.org/10.1016/j.ijresmar.2009.08.001

Robbins, S. P., \& Judge, T. A. (2012). Essentials of Organizational Behavior. Pearson Education Inc. Ruhaya, A., Saunah, Z., \& Wah, Y. B. (2012). The extent of charitable organisations' disclosures of information and its relationship with donations. Malaysian Accounting Review, 11(2), 15-38.

Sharfizie, M. S., Marinah, A., \& Ramlee, I. (2019a). Conceptualizing the impact of Leader-member Exchange in non-profit and religious organisations: The case of waqf institutions in Malaysia. Journal of Emerging Economies \& Islamic Research 7(3), 7(3), 71-85.

Sharfizie, M. S., Marinah, A., \& Ramlee, I. (2019b). Management Effectiveness in Waqf Institutions in Malaysia : A Literature Review. International Journal of Academic Research in Business and Social Sciences, 9(11), 254-271. https://doi.org/10.6007/IJARBSS/v9-i11/6546

Siraj, S. A. (2012). An Empirical Investigation into the Accounting, Accountability and Effectiveness of Waqf Management in the State Islamic Religious Councils (SIRCS) In Malaysia. [Doctoral dissertation, Cardiff University]. http://orca.cf.ac.uk/46875/

Thaker, M. A. B. M. T., Mohammed, M. O., Duasa, J., \& Abdullah, M. A. (2016). Developing Cash Waqf Model as an Alternative Source of Financing for Micro Enterprises in Malaysia. Journal of Islamic Accounting and Business Research, 7(4).

Urbach, N., \& Ahlemann, F. (2010). Structural Equation Modeling in Information Systems Research Using Partial Least Squares. Journal of Information Technology Theory and Application, 11(2), 5-40.

Wallis, J., \& Dollery, B. (2006). Revitalizing the contribution non-profit organizations can make to the provision of human services. International Journal of Social Economics, 33(7), 491-511. https://doi.org/10.1108/03068290610673261

Yuan, K.-H., Wu, R., \& Bentler, P. M. (2009). Ridge Structural Equation Modeling with Correlation Matrices for Ordinal and Continuous Data. The British Journal of Mathematical and Statistical Psychology, 64((1)), 107-133. https://doi.org/10.1348/000711010x497442.

Zainon, S., Atan, R., Wah, Y. B., \& Ahmad, R. A. R. (2012). Information disclosure by charity organizations. Recent Advances in Business Administration., 39-44.

Zainon, S., Atan, R., \& Wah, Y. B. (2014). An empirical study on the determinants of information disclosure of Malaysian non-profit organizations. Asian Review of Accounting, 22(1), 35-55. https://doi.org/10.1108/ARA-04-2013-0026 